Mikołaj Tarkowski (Słupsk)

\title{
Stan wojenny w prowincjach północno-zachodnich Imperium Rosyjskiego i jego wpływ na status prawny poddanych cesarza Aleksandra II (1855-1881)
}

„Wakacje 1861 roku znowu spędziliśmy w kraju, lecz już w zupełnie innej atmosferze. Epopeja Garibaldiego i prawie dokonane zjednoczenie Włoch rozpaliły już były »od morza do morza« łatwo zapalne głowy polskie. W Rosji panowały na wskroś prądy liberalne i reformatorskie, demonstracje warszawskie już były w toku. Za nimi żałoba, czamarki itp.". Tymi słowami na kartach swych pamiętników Hipolit Korwin-Milewski, przedstawiciel konserwatywnego kręgu litewskiego ziemiaństwa, wspominał lato 1861 roku w prowincjach północno-zachodnich, które przeszło do historii pod znakiem manifestacji społecznych, i, co nie mniej ważne z punktu widzenia tematu niniejszego artykułu, reakcji władz rządowych na wystąpienia publiczne. Działania podjęte wówczas przez Aleksandra II w sferze prawodawczej wyznaczyły w znacznym stopniu bieg wydarzeń w następnej dekadzie.

W latach 1861-1872 na terenach sześciu guberni (wileńskiej, grodzieńskiej, kowieńskiej, mińskiej, witebskiej i mohylewskiej), wchodzących w skład Kraju Północno-Zachodniego (Siewiero-zapadnyj kraj), należy odnotować obowiązywanie kilku najistotniejszych aktów prawnych oraz zarządzeń i instrukcji władz administracyjnych, które w sposób bezpośredni bądź pośredni wpływały na status prawny mieszkańców tych ziem w okresie stanu wojennego (wojennoje położenije). W tym miejscu wypada dodać, iż stan wojenny w prowincjach litewsko-białoruskich wprowadzany i znoszony był stopniowo w poszczególnych guberniach i powiatach. s. 28 .

${ }^{1}$ Cyt. za: H. Korwin-Milewski, Siedemdziesiąt lat wspomnień (1855-1925), Warszawa 1993, 
Pierwsze manifestacje w Wilnie odbyły się wkrótce po wydarzeniach mających miejsce w Królestwie Polskim, w szczególności po demonstracjach zorganizowanych w Warszawie w dniach 13 i 15 lutego 1861 roku. W organizację zgromadzeń publicznych w grodzie Giedymina zaangażowany był wileński powiatowy marszałek szlachty hrabia Jan Tyszkiewicz ${ }^{2}$. W kwietniu 1861 roku generał-gubernator wileński Władimir Nazimow (1855-1863), po uzyskaniu zgody cesarza Aleksandra II, odwołał hrabiego Tyszkiewicza z zajmowanej przez niego funkcji. Ta decyzja wywołała wśród miejscowej szlachty głęboki sprzeciw, wyrażony w trakcie zwołanego w czerwcu 1861 roku sejmiku, którego celem był wybór kandydata do objęcia wakującego stanowiska. Zebrana wówczas szlachta procedowała w związku z odbywającymi się wyborami, a jednocześnie czterdziestu sześciu jej przedstawicieli podpisało adres do cesarza rosyjskiego, w którym wyrażali oni poparcie dla hrabiego Jana Tyszkiewicza. W odpowiedzi na zachowanie szlachty powiatu wileńskiego Władimir Nazimow nie zaakceptował uchwały wyborczej podjętej przez sejmik. Dodatkowo czterech z sygnatariuszy adresu nakazał pozbawić funkcji wykonywanych w ramach samorządu stanowego i przymusowo przesiedlić, wyznaczając im do zamieszkania miejsca znajdujące się w innych guberniach. Relacje między szlachtą litewską a generał-gubernatorem wileńskim stawały się coraz bardziej napięte $\mathrm{w}$ wyniku zorganizowania demonstracji w związku z krótką wizytą hrabiego Andrzeja Zamoyskiego w powiecie białostockim $\mathrm{w}$ guberni grodzieńskiej. $\mathrm{Z}$ relacji urzędników policji, którzy wysyłali w tej sprawie raporty do kancelarii generał-gubernatora wileńskiego, wynikało, iż żegnający Zamoyskiego licznie zgromadzeni ludzie wręczali kwiaty, kłaniali się mu zdejmując nakrycia z głów, a ponadto skandowali hasło: »Hura Zamoyski, pierwszy szlachcic Polski! «

Niepokój władz rządowych wzbudziły także zgromadzenia publiczne i manifestacje patriotyczne związane z uroczystościami poświęconymi kolejnej rocznicy zawiązania w 1413 roku unii horodelskiej. W guberniach północno-zachodnich na przełomie lipca i sierpnia 1861 roku dla uczczenia tego wydarzenia odbyło się wiele demonstracji i uroczystości kościelnych. Największa z nich miała miejsce 31 lipca 1861 roku na moście na Niemnie, który łączył dwie miejscowości: Kowno (położone w Imperium Rosyjskim) i Aleksotę (położoną w Królestwie Polskim) ${ }^{4}$. Pomniejszy wiec odbył się w Rosieniach (gubernia kowieńska). W jego trakcie

\footnotetext{
${ }^{2}$ Lietuvos centrinis valstybès archyvas (LCVA), F. 1258, ap. 1, b. 45, msp., Marszałkowie guberni wileńskiej. Kolekcja ks. Waleriana Meysztowicza, k. 3.

${ }^{3}$ Lietuvos valstybès istorijos archyvas (LVIA), F. 439, ap. 1, b. 26, msp., Sostawlennyj w Ministerstwie Wnutriennich Dieł oczerk obszczago choda diet w Zapadnom kraje s naczała 1861 goda po nastojaszczeje wremia, dat. [Wilno] 1863 r., k. 2.

${ }^{4}$ W. Przyborowski, Historia dwóch lat. 1861-1862. Część pierwsza. Rok 1861, t. III (czerwiec-grudzień), Kraków 1894, s. 150.
} 
młodzi mężczyźni i kobiety śpiewając pieśni patriotyczne uczestniczyli w procesji. Natomiast w Mińsku Litewskim, tego samego dnia, pośród zgromadzonych w kościele na mszy świętej ludzi, byli mężczyźni w konfederatkach na głowie oraz kobiety odziane w czarne żałobne suknie. W guberni witebskiej w powiecie drysieńskim i lucyńskim miejscowa ludność odśpiewała - zdaniem władz rosyjskich - oburzające (wozmutitielnyje) pieśni kościelne. Z kolei 6 sierpnia 1861 roku w miejscowości Czaszniki (powiat lucyński) w związku z uroczystościami upamiętnienia rocznicy powołania unii polsko-litewskiej wierni przeszli $\mathrm{w}$ procesji wokół kościoła, a następnie „na klęczkach zaśpiewali oburzające pieśni patriotyczne"s.

W czasie, gdy do ministra spraw wewnętrznych Piotra Wałujewa docierały pierwsze raporty na temat demonstracji w Kownie i Aleksocie, władze rządowe w poszczególnych guberniach podejmowały środki mające na celu zaprowadzenie spokoju publicznego. Gubernator miński hrabia Eduard Keller zadecydował o rozbrojeniu mieszkańców zamieszkujących podległą mu gubernię. Jednocześnie w Sankt Petersburgu powołano specjalny komitet, który miał przygotować projekty aktów prawnych przewidujących ustanowienie środków przeciwdziałających eskalacji społecznego niepokoju w guberniach zachodnich Cesarstwa Rosyjskiego. To gremium zaproponowało między innymi: 1) utworzenie sądów policyjnych, 2) wzmocnienie wojsk rozlokowanych w tej części Imperium, w tym skierowanie do służby wojskowej kilku dodatkowych oficerów, 3) przygotowanie projektu aktu prawnego regulującego procedurę wprowadzenia stanu wojennego w tych guberniach i częściach guberni, w których byłoby to potrzebne, 4) przeprowadzenie w krótkim czasie akcji rozbrojenia mieszkańców prowincji zachodnich, 5) w guberniach, w których wprowadzonoby stan wojenny, naczelnicy mieli pozostawać pod „głównym dowództwem” generał-gubernatora, 6) zabezpieczenie puli środków finansowych, na podstawie których gubernatorowie powoływaliby do służby tajnych policyjnych agentów, 7) wprowadzenie zakazu organizowania i uczestnictwa $\mathrm{w}$ jakichkolwiek demonstracjach i zgromadzeniach publicznych, 8) nałożenie na mieszkańców miejscowości, w których będą miały miejsce manifestacje, obowiązku utrzymywania wojsk zaprowadzających porządek w poszczególnych powiatach (wojennyj postoj), 9) niestosowanie środków przymusu wobec duchownych w kościołach i parafiach, lecz kierowanie spraw księży podejrzanych o udział w demonstracjach na drogę sądową, 10) utworzenie specjalnej komisji śledczej w Mińsku, Wilnie i Kijowie do rozpatrywania spraw przestępstw politycznych, 11) wyznaczenie gubernatorom i naczelnikom powiatu zadania po-

${ }^{5}$ LVIA, F. 439, ap. 1, b. 26, msp., Sostawlennyj w Ministerstwie Wnutriennich Diet oczerk obszczago choda diet w Zapadnom kraje s naczała 1861 goda po nastojaszczeje wremia, [Wilno] 1863 r., k. 2-3v. 
legającego na wyjaśnieniu ludności „umiarkowanymi i ostrożnymi słowami” celów, które będzie realizował rząd ${ }^{6}$.

Rekomendacje przedstawione przez specjalny komitet legły u podstaw rozporządzenia o środkach wojennych, jakie mają być przedsiębrane w niektórych okolicach guberni zachodnich z dnia 5 sierpnia 1861 roku, które zostało ogłoszone na podstawie dekretu Senatu Rządzącego w dniu 9 sierpnia tego samego roku? ${ }^{7}$ Mocą tego aktu prawnego uprawniono generał-gubernatora wileńskiego do proklamowania stanu wojennego, bez konieczności uzyskiwania zgody rosyjskiego cesarza. Pozycja tego urzędnika została bezsprzecznie wzmocniona, jednakże normy rozporządzenia nie obejmowały, pozostających w tym czasie poza zakresem jego nadzoru, guberni białoruskich (mińskiej, mohylewskiej i witebskiej) ${ }^{8}$. Z kolei 16 sierpnia 1861 roku Aleksander II określił normy, którymi mieli się kierować powiatowi urzędnicy policyjni. Wola cesarza w tym zakresie została ogłoszona na podstawie dekretu Senatu Rządzącego z dnia 24 sierpnia 1861 roku o czasowych poleceniach dla policji powiatowych. W tym akcie prawnym zawarto definicję legalną ,jawnego sprzeciwu” wobec postanowień władz publicznych, którą funkcjonariusze policji mieli brać pod uwagę w trakcie wykonywania przez nich czynności służbowych. „Jawnym sprzeciwem” były przypadki, w których poddani uciekali się do użycia siły fizycznej wobec urzędników i funkcjonariuszy państwowych. Ponadto do tej kategorii zaliczono zachowania polegające na odmowie zastosowania się do poleceń policji, mających na celu przywrócenie porządku publicznego'.

Propozycje specjalnego komitetu zostały także zrealizowane w obszarze funkcjonowania sądów policyjnych. Komitet Ministrów przedstawił swoje stanowisko w tej sprawie, a monarcha rosyjski 5 sierpnia 1861 roku potwierdził powołanie tego rodzaju instytucji. Następnie 9 sierpnia 1861 roku Senat ogłosił ukaz o utworzeniu sądów policyjnych w guberniach zachodnich. W skład sądów policyjnych wchodził sędzia powiatowy, asesor, a także komisarz wyznaczony przez miejscowego gubernatora. Instancją odwoławczą dla orzeczeń sądów policyjnych był apelacyjny sąd policyjny. W guberniach zachodnich przewidzia-

${ }^{6}$ LVIA, F. 439, ap. 1, b. 26, msp., Sostawlennyj w Ministerstwie Wnutriennich Dieł oczerk obszczago choda diet $w$ Zapadnom kraje s naczała 1861 goda po nastojaszczeje wremia, dat. [Wilno] 1863 r., k. $4 \mathrm{v}-5$.

${ }^{7}$ LVIA, F. 439, ap. 1, b. 8, rkps, Ukaz Sienata o prawitach obiawlenija wojennago położenija w gubiernijach Siewiero zapadnogo kraja (kopija). Kolekcja muzeum i archiwum hrabiego Michaiła Murawjowa, k. 1; zob. też: D. Szpoper, Pomiędzy caratem a snem o Rzeczypospolitej. Myśl polityczna i działalność konserwatystów polskich w guberniach zachodnich Cesarstwa Rosyjskiego w latach 1855-1862, Gdańsk 2003, s. 96.

${ }^{8}$ Ibidem, s. 97.

${ }_{9}$ O wriemiennoj nakazie ujezdnym policijam, 16 VIII 1861, [w:] Polnoje Sobranije Zakonow Rossijskoj Impierii, t. 36, cz. 2, Sankt Peterburg 1863, s. 237. 
no utworzenie dwóch takich sądów: w Wilnie i Kijowie. Sądy policyjne były powołane do rozpatrywania spraw z zakresu przestępstw politycznych, w tym między innymi uczestnictwa $\mathrm{w}$ demonstracjach i publicznego śpiewania pieśni patriotycznych $^{10}$.

Intensywność i skala wydarzeń pierwszej połowy 1861 roku, a także manifestacje w lipcu i sierpniu, związane z uczczeniem rocznicy zawiązania unii polsko-litewskiej, skłoniły generał-gubernatora wileńskiego Władimira Nazimowa do podjęcia decyzji o wprowadzeniu stanu wojennego. Rozporządzenie w tej sprawie wydał w dniu 23 sierpnia 1861 roku. Stan wojenny ustanowiono na terytorium Wilna, Grodna, Białegostoku, Bielska, Brześcia Litewskiego i całej guberni kowieńskiej, z wyjątkiem powiatu jezioroskiego (nowoaleksandrowskiego) ${ }^{11}$. Generał-gubernator Nazimow skorzystał zatem z kompetencji płynącej z przepisów rozporządzenia $\mathrm{z}$ dnia 5 sierpnia 1861 roku. Jednakże decyzja ta wywołała konflikt polityczny z ministrem spraw wewnętrznych Piotrem Wałujewem, gdyż Nazimow nie skonsultował możliwości skorzystania ze swych uprawnień z władzami ministerialnymi. Dla Piotra Wałujewa niewystarczającym argumentem był fakt, iż Władimir Nazimow rozkaz wprowadzenia stanu wojennego ustalił z osobami pozostającymi w bezpośrednim otoczeniu Aleksandra $\mathrm{II}^{12}$. Wspomnienia Wałujewa świadczą o tym, że relacje między nim a jego podwładnym były w tym czasie napięte. Na kartach swego dziennika stwierdzał, że decyzja o wprowadzeniu stanu wojennego była przedwczesna. Zaznaczył przy tym, że starał się uświadomić Nazimowowi możliwe skutki takiego kroku, który mógł na europejskich salonach politycznych wywrzeć wrażenie, że strategia działania cesarza Aleksandra II wobec Kraju Zachodniego i Królestwa Polskiego jest niespójna. Minister spraw wewnętrznych Imperium Rosyjskiego wykluczył bowiem możliwość wprowadzenia stanu wojennego w prowincjach zachodnich, a dopiero później - niejako w następnym kroku - w Warszawie i innych guberniach Królestwa Polskiego ${ }^{13}$.

${ }^{10}$ Ob uczrieżdienii Policiejskich Sudow w Zapadnych gubiernijach, 5 VIII 1861, [w:] Potnoje Sobranije Zakonow Rossijskoj Impierii, t. 36, cz. 2, Sankt Peterburg 1863, s. 221-223; zob. też: D. Szpoper, op.cit., s. 99.

${ }^{11}$ LVIA, F. 439, ap. 1, b. 26, msp., Sostawlennyj w Ministerstwie Wnutriennich Dieł oczerk obszczago choda diet w Zapadnom kraje s naczała 1861 goda po nastojaszczeje wremia, dat. [Wilno] 1863 r., k. 5v; zob. też: [J. Dąbrowski] J. Grabiec, Powstanie styczniowe 1863-1864, WarszawaKraków 1921, s. 31.

${ }_{12}$ M. Dołbiłow, Projekt naciostroitielstwa w politikie włastiej w Zapadnom kraje, [w:] M. Dołbiłow, A. Miller (red.), Zapadnyje okrainy Rossijskoj impierii, Moskwa 2007, s. 162-163.

${ }_{13}$ P. Zajonczkowskij (red.), Dniewnik P.A. Watujewa ministra wnutriennich diet $w$ dwuch tomach 1861-1864, t. I, Moskwa 1961, zapis z 24 sierpnia 1861 r., s. 108. Piotr Wałujew, po upływie przeszło roku od momentu ogłoszenia stanu wojennego, oceniając plany polityczne Władimira Nazimowa zakładające zjednoczenie Litwinów i Białorusinów wokół wspólnego celu, którym było 
Osłabienie manifestacji ulicznych, a także tych powstających przy okazji świąt kościelnych, spowodowało, iż władze rządowe podjęły decyzję o zniesieniu stanu wojennego z dniem 1 października 1862 roku w Wilnie oraz guberni grodzieńskiej, z wyłączeniem Grodna. W tym mieście stan wojenny utrzymywał się do 9 listopada, a zatem do czasu wydania rozporządzenia przez gubernatora grodzieńskiego Iwana von Hallera ${ }^{14}$. Odwołanie stanu wojennego nie zmieniło w zasadzie coraz ostrzejszego kursu przyjętego przez generał-gubernatora wileńskiego Władimira Nazimowa wobec umiarkowanych środowisk szlacheckich na Litwie i Białorusi ${ }^{15}$.

Według Michała Murawjowa, sprawującego od maja 1863 roku do kwietnia 1865 roku funkcję generał-gubernatora wileńskiego ${ }^{16}$, reakcja i podejmowane przez władze rządowe działania, mające na celu powstrzymanie organizatorów kolejnych manifestacji odbywających się w Kraju Północno-Zachodnim od sierpnia 1861 roku do czasu wybuchu powstania styczniowego, były nieskuteczne. Murawjow zarzucił Władimirowi Nazimowowi, iż podległe mu służby wykazywały się wyłącznie zamiarem zastosowania „kar i przestróg” wobec osób angażujących się w działalność antypaństwową. Za niewystarczające uznał także wprowadzenie środków zapobiegawczych na drodze podejmowanych przez Nazimowa decyzji o charakterze administracyjnym ${ }^{17}$. Generał-gubernator wileński Michaił Murawjow podkreślał także, iż jego poprzednik nie wykazał się inicjatywą w sprawie powołania sądów policyjnych. Murawjow wskazywał, że idea powołania sądów policyjnych nie zrodziła się w kręgu urzędników pracujących w kancelarii kierowanej przez Nazimowa, lecz wyszła od petersburskich elit politycznych, skupionych wokół kierującego pracami III Oddziału Kancelarii Własnej Jego Cesarskiej Mości księcia Wasilijego Dołgorukowa ${ }^{18}$ oraz ministra spraw wewnętrznych Piotra Wałujewa ${ }^{19}$, nota bene rywalizującego w tym czasie

przeciwdziałanie „polskiej propagandzie” w guberniach północno-zachodnich, określił te plany mianem „manifestu à la Garibaldi”, który mógłby zachwiać podstawami monarchii Romanowów; zob. ibidem, zapis z dnia 20 września 1862 r., s. 190.

${ }^{14}$ J. Komar, Grodzieńskie manifestacje przed powstaniem styczniowym, „Przegląd Historyczny" 1960, t. 51, z. 1, s. 119.

${ }^{15}$ D. Fajnhauz, Śladami Wielopolskiego. Wiktor Starzeński i jego projekty ugody polsko-rosyjskiej na Litwie i Białorusi (1861-1863), „Przegląd Historyczny” 1994, t. 85, z. 3, s. 248.

${ }_{16}$ Je. Fiedosowa, Graf M.N. Murawjow-Wilenskij (1796-1866): Żizn na stużbie impierii, Moskwa 2015, s. 124.

${ }^{17}$ LVIA, F. 439, ap. 1, b. 26, msp., Sostawlennyj w Ministerstwie Wnutriennich Diel oczerk obszczago choda diet w Zapadnom kraje s naczała 1861 goda po nastojaszczeje wremia, [Wilno] 1863 r., k. 2 v.

${ }^{18}$ B. Ananicz, R. Ganielin, W. Pleszkow, A. Sokołow, A. Camutali, W. Czernucha (red.), Uprawlenczeskija elita Rossijskoj imperii. Istorija ministierstw. 1802-1917, Sankt Peterburg 2008, s. 58.

19 Ibidem, s. 274. 
z Michaiłem Murawjowem o wpływy na dworze rosyjskim. W pierwszych dniach lipca, w ostatniej fazie przygotowań związanych z wprowadzeniem sądów policyjnych, Władimir Nazimow, wykazując pewne niezdecydowanie, poparł ten projekt, jednak zasugerował, że „metody administracyjne” mogły okazać się w tym przypadku skuteczniejsze. Podobnego zdania był generał-gubernator kijowski książę Illarion Wasilczikow, który inicjatywę powołania sądów policyjnych uznał za potrzebną, lecz - jego zdaniem - należało ją uzupełnić o rozwiązania prawne umożliwiające orzekanie kar przez te organy sądowe wyłącznie w „skrajnych przypadkach" 20 .

Michaił Murawjow w drugiej połowie 1863 roku dokonując przeglądu działań podejmowanych przez miejscową administrację zauważył, iż zarówno wprowadzenie stanu wojennego w sierpniu 1861 roku, utworzenie sądów policyjnych, jak również „szerokie swobody”, które na poddanych zamieszkujących gubernie litewsko-białoruskie rozpościerały władze rządowe nie przyniosło właściwych rezultatów. Brak skutecznych działań zapewniających utrzymanie spokoju i porządku publicznego był rekompensowany zastosowaniem rozporządzeń administracyjnych, które Murawjow nazwał „półśrodkami”, wyłącznie „uśmierzającymi” skutki aktów niesubordynacji popełnianych przez dużą część poddanych zamieszkujących gubernie północno-zachodnie. Wileński generał-gubernator z pewnym rozczarowaniem zauważał, iż władze rządowe, oprócz mas włościańskich, nie pozyskały żadnej sojuszniczej grupy społecznej, która mogłaby sprzyjać polityce prowadzonej przez administrację rosyjską, a jednocześnie nie dążyłaby do sytuacji skutkujących, rozlewem krwi. Dodatkowo wprowadzony na tych terenach stan wojenny w praktyce przejawiał się jedynie zastosowaniem środków o charakterze administracyjno-karnym. W czasie obowiązywania tego nadzwyczajnego stanu - zdaniem Murawjowa - policja powinna działać z całą stanowczością, zaś sądy wojenne powinny wydawać w pełni wykonywane orzeczenia na podstawie kodeksu karno-wojskowego. O tym, że za Nazimowa organy policyjne podejmowały środki zbyt łagodne miał świadczyć przypadek Michajłowskiego, właściciela majątku ziemskiego położonego w guberni kowieńskiej. Ten szlachcic litewski został oskarżony o posiadanie broni oraz kilku pudeł prochu. Murawjow był zdumiony, że wobec osoby, która nie zastosowała się do nakazu rozbrojenia ludności cywilnej zastosowano jedynie dozór policyjny z jednoczesnym zakazem opuszczania domu ${ }^{21}$.

${ }^{20}$ LVIA, F. 439, ap. 1, b. 26, msp., Sostawlennyj w Ministerstwie Wnutriennich Dieł oczerk obszczago choda diet w Zapadnom kraje s naczała 1861 goda po nastojaszczeje wremia, [Wilno] 1863 r., k. 3.

${ }^{21}$ LVIA, F. 439, ap. 1, b. 26, msp., Sostawlennyj w Ministerstwie Wnutriennich Diet oczerk obszczago choda diet w Zapadnom kraje s naczała 1861 goda po nastojaszczeje wremia, [Wilno] 1863 r., k. $8 \mathrm{v}$. 
Gubernator wileński krytycznie oceniał także działanie sądów policyjnych, które jego zdaniem nie spełniały swojej funkcji, nie stosując się do instrukcji ministra spraw wewnętrznych, a wobec uczestników antyrządowych manifestacji wykazując bierność lub bezradność2 ${ }^{2}$. W 1863 roku, podsumowując założenia polityki Władimira Nazimowa i jego wpływ na miejscową ludność, Murawjow sformułował kilka ogólnych wniosków. Po pierwsze, wszystkie działania mające służyć zacieśnieniu więzi między Krajem Zachodnim a guberniami wewnętrznymi Imperium Rosyjskiego okazały się bezskuteczne. Po drugie, strategia władz rządowych nakierowana przez ostatnie półtora roku na zwalczenie tak zwanego „ruchu polskiego” w prowincjach północno-zachodnich odniosła wyłącznie krótkofalowy efekt. Po trzecie, władza rządowa mogła zaufać w pewnym stopniu tylko włościanom i duchownym prawosławnym, a w przypadku podejmowania newralgicznych decyzji pozostawała bez wsparcia pozostałych grup społecznych, przede wszystkim szlachty i kleru rzymskokatolickiego. Po czwarte, do tej pory służby państwowe nie wyłowiły z grona członków,,polskiej partii” głównych agitatorów działalności antypaństwowej ${ }^{23}$.

Wybuch powstania styczniowego zmusił władze rosyjskie do podjęcia zdecydowanych kroków. Aleksander II, zatwierdzając reskrypt z dnia 14 stycznia 1863 roku, udzielił nadzwyczajnych pełnomocnictw generał-gubernatorowi wileńskiemu. Normy tego aktu prawnego uprawniały Władimira Nazimowa do stawiania przed sądami wojennymi osób schwytanych z bronią w ręku, a także szybkiego wykonywania wyroków sądów polowych, po ich uprzedniej konfirmacji. Generał-gubernator wileński zyskał również kompetencje powoływania karno-wojskowych komisji śledczych, których decyzje mógł zatwierdzać, oraz podejmowania wszelkich środków mających na celu przywrócenie porządku publicznego w guberniach mu podległych ${ }^{24}$.

16 lutego 1863 roku, na podstawie przepisów rozporządzenia z dnia 5 sierpnia 1861 roku, generał-gubernator wileński Władimir Nazimow wydał cyrkularz $\mathrm{w}$ sprawie stanu wojennego. Zgodnie z jego postanowieniami wojennoje położe-

${ }^{22}$ LVIA, F. 439, ap. 1, b. 26, msp., Sostawlennyj w Ministerstwie Wnutriennich Dieł oczerk obszczago choda diet w Zapadnom kraje s naczała 1861 goda po nastojaszczeje wremia, [Wilno] 1863 r., k. 9.

${ }^{23}$ LVIA, F. 439, ap. 1, b. 26, msp., Sostawlennyj w Ministerstwie Wnutriennich Diet oczerk obszczago choda diet w Zapadnom kraje s naczała 1861 goda po nastojaszczeje wremia, [Wilno] 1863 r., k. 9-10v.

${ }^{24}$ O obleczenii Wilenskago Wojennago, Grodnienskago, Minskago, i Kowienskago Gienerat-Gubiernatora osoboju włastju i priedostawlenii jemu priniat miery, nieobchodimyja k ochranieniju spokojstwa w kraje, po stuczaju bezporiadkow, woznikawszich w Carstwie Polskom, 14 I 1863, [w:] Polnoje Sobranije Zakonow Rossijskoj Imperii, t. 38, cz. 1, Sankt Peterburg 1866, s. 60-61; zob. też: R. Amirow, Iz opyta wojenno-policejskago uprawlenija w Rossijskoj impierii, „Wiestnik Akademii ekonomiczeskoj bezopasnosti MWD Rossii” 2009, nr 1, s. 58. 
nije zostało wprowadzone na terenie guberni wileńskiej, kowieńskiej i grodzieńskiej. Okólnik ten nakładał na organy administracji państwowej określone obowiązki. Organy policji ziemskiej i miejskiej nadzorowane były przez naczelników wojennych. Zarząd nad sprawami związanymi ze stanem wojennym, a przede wszystkim „tłumieniem nieporządków o charakterze politycznym” należał do Sztabu Wojsk Wileńskiego Okręgu Wojskowego. Wszelkie decyzje w tym zakresie podejmował osobiście naczelnik Sztabu lub generał-gubernator wileński. Sprawy osób oskarżonych o przestępstwa polityczne, ,względnie [co] do ważności przestępstwa", rozstrzygały sądy wojenne ${ }^{25}$. Generał-gubernator Murawjow okólnikiem z dnia 13 lipca 1863 r. nakazał w ciągu doby od schwytania oddawać pod sąd wojenny przedstawicieli ziemiaństwa, szlachty i duchowieństwa oraz po konfirmacji ${ }^{26}$ wykonywać na cywilach wyrok kary śmierci ${ }^{27}$. Skazanych na zesłanie na Syberię i odebranie praw wynikających z przynależności do stanu uprzywilejowanego lokowano głównie w guberniach tobolskiej i tomskiej. Wydatki związane ze zsyłką Murawjow planował pokrywać z sum pozyskanych z przeprowadzanych jednocześnie sekwestrów i konfiskowania majątków ziemskich położonych w guberniach północno-zachodnich ${ }^{28}$.

Zgodnie z postanowieniami cyrkularza w sprawie stanu wojennego sądy wojenne miały kierować się przepisami: 1) Zbioru praw wojskowych (Swod wojennych postanowlenij) - wydanie z 1859 roku, 2) Procedury sądowej w sprawach kryminalnych - t. XV Zbioru Praw Cesarstwa Rosyjskiego (wydanie z 1857 roku), 3) Kodeksu Kar Głównych i Poprawczych z 1845 roku (Utożenije o nakazanijach ugolownych $i$ isprawitielnych). Sprawy rozstrzygnięte przed sądami wojennymi po konfirmacji generał-gubernatora były przekazywane do Departamentu Audytorskiego, działającego w strukturze ministerstwa wojny. Kopie aktów konfirmacyjnych przekazywano do kancelarii ministra wojny w celu zameldowania o nich cesarzowi rosyjskiemu. Dokumenty, zgodnie z postanowieniem ministra wojny Dmitrija Milutina $^{29} \mathrm{z}$ dnia 14 grudnia 1861 roku, były udostępniane także mini-

${ }^{25}$ Cyrkularz dowódcy Wileńskiego Okręgu Wojennego i wojennego wileńskiego, kowieńskiego i mińskiego generał-gubernatora $\mathrm{nr}$ 35, 16 lutego $1863 \mathrm{r}$. W sprawach stanu wojennego, [w:] W. Studnicki (red.), Rok 1863. Wyroki śmierci, Wilno 1923, s. XI-XIV.

${ }^{26}$ Od końca lipca 1863 r., konfirmowanie wyroku mogło być dokonywane przez naczelników wojennych; zob.: S. Krzemiński, Dwadzieścia pięć lat Rosji w Polsce (1863-1888). Zarys historyczny, Lwów 1892, s. 54.

${ }^{27}$ Priekraszczenije miatieża, [w:] N. Cyłow (red.), Sbornik rasporiażenij grafa Michaiła Nikotajewicza Murawjowa po usmirieniju polskowo miatieża $w$ Siewiero-zapadnych gubierniach 1863-1864, Wilno 1866, s. 290; zob. też: S. Krzemiński, op.cit., s. 44.

${ }^{28}$ LVIA, F. 439, ap. 1, b. 31, rkps, Pismo generał-gubernatora wileńskiego Michaiła Murawjowa do ministra Piotra Wałujewa, dat. Wilno 11 XII 1863 r. Kolekcja archiwum i muzeum hrabiego Michaiła Murawjowa, k. 1v.

29 Uprawlenczeskija elita Rossijskoj..., s. 144. 
strowi spraw wewnętrznych oraz szefowi III Oddziału Kancelarii Własnej Jego Cesarskiej Mości. Prokuratorami posiadającymi prawo występowania przed sądami wojskowymi byli urzędnicy audytorscy, wymienieni w cyrkularzu z 16 lutego 1863 roku, działający w Wilnie, Grodnie, Białymstoku, Kownie i guberni mińskiej ${ }^{30}$.

Wobec osób oskarżonych o działalność powstańczą stosowano także zesłanie do guberni centralnych lub na Sybir w trybie nakazu administracyjnego. Instytucja ta nie miała charakteru stricte karnego i właśnie dlatego decyzja o zsyłce mogła zostać podjęta $\mathrm{w}$ ramach prerogatyw przysługujących aparatowi rządowemu w Kraju Północno-Zachodnim ${ }^{31}$. Od 31 sierpnia 1864 roku, z uwagi na zmniejszającą się liczbę spraw, władze rządowe zadecydowały o ograniczeniu liczby wydawanych nakazów administracyjnych skutkujących zesłaniem ${ }^{32}$.

Wraz z rozwojem walk i działalności ruchu powstańczego cesarz Aleksander II, w nawiązaniu do wcześniejszych postanowień wynikających z aktu amnestii ogłoszonego w dniu 31 marca 1863 roku, zatwierdził w dniu 11 maja 1863 roku przepisy wprowadzające podział powstańców na pięć kategorii. Wprowadzając niniejsze przepisy w życie miał, jak twierdził, na uwadze przywrócenie spokoju w „guberniach zarażonych buntem”. Podkreślił, że celem władz było nie tylko surowe, ale również sprawiedliwe ukaranie winnych uczestnictwa w powstaniu, szczególnie tych, którzy po upływie terminu określonego aktem amnestii nie złożyli dobrowolnie broni ${ }^{33}$.

Do pierwszej grupy zaliczono dowódców oddziałów wojskowych, członków organów władz powstańczych oraz osoby przybywające z zagranicy i wstępujące do jednostek zbrojnych. W drugiej kategorii znaleźli się insurgenci, którzy z bronią w ręku lub poprzez swą pozycję społeczną i wykształcenie wspierali rozwój ruchu powstańczego. W tym miejscu w sposób wyraźny wskazywano na szlachtę i duchowieństwo, obwiniane za negatywne oddziaływanie na lud zamieszkujący osady wiejskie. Do trzeciej kategorii przypisano chłopów, niepełnoletnich i osoby o niskim statusie materialnym. Powstańcy zaliczeni do czwartej kategorii mieli wspierać „,buntownicze” działania poprzez udzielanie schronienia, przeznaczanie sum pieniężnych czy niedostarczanie gubernatorom informacji na temat formo-

${ }^{30}$ Cyrkularz dowódcy Wileńskiego Okręgu Wojennego..., s. XIV-XV.

${ }_{11}$ J. Bardach, S. Grodziski, M. Senkowska-Gluck (red.), Historia Państwa i Prawa Polski, t. IV: K. Grzybowski, Od uwłaszczenia do odrodzenia, Warszawa 1982, s. 248; zob. też: L. Zasztowt, Zsyłki i przesiedlenia ludności polskiej z zachodnich guberni Cesarstwa Rosyjskiego po powstaniu styczniowym, „Przegląd Wschodni” 1998, z. 2, s. 239; A. Markiewicz, Kobiety i rodziny powstańców styczniowych zesłanych w głąb Rosji, Warszawa 2018, s. 13.

${ }^{32}$ S. Krzemiński, op.cit., s. 55.

${ }^{33}$ Podziat powstańców na kategorię. (Przepisy zatwierdzone przez cesarza w dniu 11 (23) maja 1863 r., [w:] Rok 1863. Wyroki śmierci..., s. XVI. 
wania się i ruchów bojowych, i „szajek powstańczych”. Z kolei uczestnicy „,zbrojnego buntu", którzy złożyli broń do 1 maja 1863 roku, zostali zakwalifikowani do piątej grupy. Michaił Murawjow, wykonując wolę cesarza Aleksandra II, wydał w sprawie kategoryzacji powstańców odpowiedni okólnik ${ }^{34}$.

Normy zawarte w rozporządzeniu Aleksandra II z dnia 5 sierpnia 1861 roku, były wykonywane przez urzędników podległych generał-gubernatorowi wileńskiemu. Po objęciu funkcji generał-gubernatora przez Michaiła Murawjowa, władze rządowe postanowiły - na mocy okólników z dnia 8 i 9 maja 1863 roku - iż stanem wojennym zostanie objęty większy obszar Kraju Północno-Zachodniego. Stan wojenny rozciągnięto bowiem na teren guberni mińskiej, mohylewskiej i witebskiej ${ }^{35}$. Dodatkowo Murawjow wydał w dniu 24 maja 1863 roku specjalną instrukcję. Od maja 1863 roku do stycznia 1864 roku była ona trzykrotnie uzupełniana (I, II i III-tie dopotnienije $k$ Instrukcii). Postanowienia instrukcji doprecyzowywały ustrój władz wojskowo-cywilnych w powiatach i guberniach podlegających nadzorowi generał-gubernatora wileńskiego. Wiele zawartych w niej punktów definiowało kompetencje organów administracji państwowej w okresie stanu wojennego. Dowódcy wojsk, po uzyskaniu zgody od gubernatorów wojskowych, wyznaczali urzędników do pełnienia funkcji powiatowych naczelników wojskowych, którzy obok funkcji wojskowych posiadali także pełnię władzy cywilnej w podległym im okręgu (powiecie). Wypełnianie zadań o charakterze wojskowo-policyjnym przez naczelników wojskowych wspierały powoływane pod nadzorem władz straże wiejskie ${ }^{36}$.

Instrukcja z dnia 24 maja 1863 roku ustanawiała również wyraźne wytyczne w obszarze funkcjonowania sądów wojennych. Michaił Murawjow przede wszystkim miał na celu przyśpieszenie pracy tych organów. Nakazał on bowiem składom orzekającym, aby wobec osób zakwalifikowanych do jednej z pięciu kategorii powstańców sądy wydawały wyrok bez zbędnej zwłoki ${ }^{37}$. Gubernatorzy $\mathrm{w}$ sprawie zapewnienia właściwej aprowizacji wojsk rosyjskich z jednej strony otrzymali zadanie utrzymania wojsk we właściwej kondycji, z drugiej zaś byli uprawnieni do zaspokajania potrzeb żywnościowych armii poprzez korzystanie z zapasów zboża i produktów spożywczych zgromadzonych w majątkach ziemskich należących do powstańców ${ }^{38}$.

${ }^{34}$ Miatieżniki, [w:] Sbornik rasporiażenij grafa Michaiła Nikołajewicza Murawjowa..., s. 211-212; zob. też: S. Łaniec, Białoruś w drugiej połowie XIX stulecia, Olsztyn 1997, s. 73.

${ }_{35}$ Wojennoje połozenije, okólniki z 8 i 9 V 1863 r., [w:] Sbornik rasporiażenij grafa Michaiła Nikołajewicza Murawjowa..., s. 36.

${ }^{36}$ Instrukcija, instrukcja z 24 V 1863 r., [w:] Sbornik rasporiażenij grafa Michaiła Nikołajewicza Murawjowa..., s. 102-103.

${ }^{37}$ Ibidem, s. 106.

38 Ibidem, s. 109. 
Urzędnicy podlegli generał-gubernatorowi wileńskiemu na mocy postanowień Instrukcji z 24 maja 1863 roku otrzymali także konkretne polecenia, których realizacja miała uspokoić sytuację społeczną w Kraju Północno-Zachodnim. Gubernatorzy zobowiązani zostali bowiem do ogłoszenia księżom rzymskokatolickim, a zwłaszcza proboszczom zarządzającym parafiami, że wszelka działalność opierająca się na sprzyjaniu „słowem lub czynem” ruchowi powstańczemu, w tym proklamowanie haseł politycznych lub organizowanie manifestacji i wieców patriotycznych, spotka się z zastosowaniem środków zaradczych w oparciu o przepisy karno-wojskowe. Postanowienia Instrukcji, expressis verbis stanowiły: „Wymówki, często przedstawiane, jakoby [księża] sprzyjali buntownikom pod przymusem, nie będą brane pod uwagę, ponieważ służąc przy ołtarzu mniej od innych powinni poddawać się tego typu groźbom"39.

Ta sama Instrukcja przypisywała odpowiedzialność karną bądź karno-administracyjną dyrektorom szkół średnich za niedopełnienie obowiązku właściwego nadzoru nad uczniami. Nauczyciele i dyrektorzy mieli obowiązek informowania gubernatorów lub powiatowych naczelników wojskowych o wszelkich przejawach nieposłuszeństwa i samowoli uczącej się młodzieży; o najmniejszym przypadku niesubordynacji mogącej prowadzić do rozruchów i manifestacji. Nadzór nad prawidłowym wykonywaniem tych zadań przez dyrektorów sprawował kurator Wileńskiego Okręgu Naukowego ${ }^{40}$.

Ponadto Instrukcja generał-gubernatora wileńskiego zawierała postanowienia, które w sposób pośredni ograniczały zakres uprawnień osobistych mieszkańców zamieszkujących prowincje północno-zachodnie. Władze rządowe w powiatach i guberniach miały bowiem dopilnować, aby nikt z grupy właścicieli ziemskich, drobnej szlachty, jednodworców, urzędników, księży, kupców, mieszczan nie opuszczał na dłuży czas miejsca zamieszkania bez pozwolenia organów administracyjnych $^{41}$. Obowiązywał również zakaz poruszania się pieszych po godzinie dwudziestej pierwszej, jeśli latarnie na ulicach nie były włączone. Urzędnicy podlegli generał-gubernatorowi wileńskiemu zostali poinstruowani w maju 1863 roku o konieczności nadzorowania powracających z zagranicy. Mieszkańcy prowincji zachodnich - „ziemianie i szlachta polskiego pochodzenia” - mieli obowiązek donoszenia o tym fakcie właściwemu gubernatorowi. Ponadto wprowadzono w życie okólnik z dnia 7 października 1863 roku, określający procedurę wglądu

39 Ibidem, s. 105.

${ }^{40}$ Wtoroje dopotnienije $k$ instrukcii danoj 24 maja 1863 g., [w:] Sbornik rasporiażenij grafa Michaiła Nikołajewicza Murawjowa..., s. 135.

${ }^{41}$ Tretie dopotnienije $k$ instrukcii danoj 24 maja 1863 g., [w:] Sbornik rasporiażenij grafa Michaiła Nikołajewicza Murawjowa..., s. 145. 
do paszportów i rewizji bagaży osób powracających z zagranicy ${ }^{42}$. Postanowienia instrukcji z dnia 26 września 1863 roku nakazywały służbom państwowym odnotowywanie w dokumentach takiego zdarzenia ${ }^{43}$.

Po zakończeniu powstania styczniowego władze rosyjskie zdecydowały się na stopniowe odwoływanie stanu wojennego w poszczególnych powiatach i guberniach ${ }^{44}$. W pierwszej kolejności zniesiono go mocą rozporządzenia z dnia 27 lipca 1866 roku generał-gubernatora wileńskiego Konstantina von Kaufmana (1865-1866) w trzynastu powiatach guberni mińskiej, witebskiej i mohylewskiej (w powiatach mińskim, mozyrskim, rzeżyckim, bobrujskim, wieliskim, surażskim, newelskim, horodeckim, mścisławskim, klimowickim, czausowskim, czerykowskim i horeckim). Zmniejszono także liczbę powiatowych naczelników wojskowych; od tej chwili jeden naczelnik wojskowy nadzorował sprawy w dwóch powiatach ${ }^{45}$. Decyzja Kaufmana wywołała ostrą reakcję w nieprzychylnych mu kręgach petersburskich elit politycznych. Sprawa zniesienia stanu wojennego w części powiatów Kraju Północno-Zachodniego była dyskutowana na posiedzeniach Komitetu Ministrów w dniu $9^{46}$ i 27 września 1866 roku $^{47}$. Stanowiła ona przyczynę odwołania Konstantina von Kaufmana z funkcji generał-gubernatora wileńskiego. Piotr Wałujew odnotował w swym dzienniku na początku października 1866 roku, że od cesarza otrzymał informację, iż Aleksander II poinformował Kaufmana o zamiarze powołania nowej osoby, hrabiego Eduarda Baranowa (1866-1868), na stanowisko generał-gubernatora wileńskiego ${ }^{48}$. Monarcha rosyjski nie przedstawił oficjalnie motywów tej decyzji. W tej sprawie znaczenie miały najprawdopodobniej dwie kwestie. Po pierwsze, zniesienie stanu wojennego przez Kaufmana, który nie konsultował tego zamiaru z przełożonymi, zostało potraktowane jako akt samowoli. Po drugie, wileński generał-gubernator nie od-

${ }^{42}$ Bagaż, okólnik z 7 X 1863 r., [w:] Sbornik rasporiażenij grafa Michaiła Nikołajewicza Murawjowa..., s. 23.

${ }^{43}$ Pasporty, okólnik z 26 IX 1863 r., [w:] Sbornik rasporiażenij grafa Michaiła Nikołajewicza Murawjowa..., s. 252.

${ }^{44} \mathrm{~S}$. Wiech, Epoka reakcji i „pieriedyszki”. Wileńscy generałowie-gubernatorzy wobec problemu polskiej własności ziemskiej w latach 1864-1884, „Kwartalnik Historyczny” 2008, nr 2, s. 64.

${ }^{45}$ A. Komzołowa, Politika samodierżawija $w$ Siewiero-Zapadnom kraje w epochu Wielikich rieform, Moskwa 2005, s. 210.

${ }^{46}$ P. Zajonczkowskij (red.), Dniewnik P.A. Watujewa ministra wnutriennich diet $w$ dwuch tomach 1865-1876, t. II, Moskwa 1961, zapis z 9 września 1866 r., s. 148.

${ }^{47}$ Ibidem, zapis z 27 września 1866 r., s. 152; zob. też: S. Wiech, Litwa i Białoruś. Od Murawjowa do Baranowa (1864-1868), [w:] S. Wiech (red.), Depolonizacja ziem zabranych (18641914). Koncepcje - mechanizmy decyzyjne - realizacja, t. 1, Kielce 2018, s. 155.

48 P. Zajonczkowskij (red.), Dniewnik P.A. Watujewa ministra wnutriennich dieł $w$ dwuch tomach 1865-1876 ..., zapis z 2 października 1866 r., s. 153. 
wołał obowiązywania na terenie trzynastu powiatów części okólników mających charakter represyjny, łamiąc tym samym przyjęte założenia polityczne ${ }^{49}$.

Następca hrabiego Eduarda Baranowa na stanowisku generał-gubernatora wileńskiego, Aleksander Potapow (1868-1874), podejmował działania mające na celu ograniczenie oddziaływania niektórych instytucji prawnych, które litewska szlachta uznawała za represyjne. Dalsze utrzymywanie podatku kontrybucyjnego, pobieranego od dochodu uzyskiwanego przez właścicieli majątków ziemskich, nie miało racji bytu, ponieważ w wielu guberniach i powiatach Kraju Północno-Zachodniego władze rosyjskie zdecydowały się już wcześniej na zniesienie stanu wojennego ${ }^{50}$. Z tego powodu Aleksander II wydał ukaz z dnia 12 stycznia 1871 roku.

W pierwszych miesiącach sprawowania funkcji, na mocy rozporządzenia z dnia 10 kwietnia 1868 roku, Aleksander Potapow odwołał obowiązywanie stanu wojennego w powiatach wchodzących w skład guberni mohylewskiej, mińskiej i witebskiej (w powiatach orszańskim, bychowskim, słuckim, nowogródzkim, witebskim, siebieskim, lepelskim i połockim). We wrześniu tego samego roku stan wojenny skończył się w pozostałych powiatach prowincji białoruskich, z wyjątkiem czterech miast: Mińska Litewskiego, Mohylewa, Nowogródka i Dyneburga. W kolejnym miesiącu zniesiono stan wojenny w guberniach litewskich: wileńskiej i grodzieńskiej. W 1871 roku proces ten był już bardzo zaawansowany i objął większość powiatów, z wykluczeniem Wilna, Kowna, Grodna, Trok, Bielska, Białegostoku i Brześcia Litewskiego. Ostatecznie w kwietniu 1872 roku zniesiono stan wojenny w dwóch powiatach guberni kowieńskiej: telszewskim i rosieńskim ${ }^{51}$.

Stan wojenny na terenie guberni północno-zachodnich, wprowadzony w 1861 roku i obowiązujący - z krótką przerwą - do 1872 roku, stanowił istotny okres w dziejach guberni północno-zachodnich pod rządami dynastii Romanowów. W tym czasie ustanowiono bowiem szereg aktów prawnych oraz instrukcji i rozporządzeń administracyjnych, które mając charakter dyskryminacyjny, stawiały w gorszej sytuacji prawnej część poddanych cesarza Aleksandra II. W opinii władz rządowych cyrkularze wprowadzające stan wojenny w kolejnych powiatach i guberniach Kraju Północno-Zachodniego miały na celu przywrócenie ładu i porządku publicznego. Jednak stan, który konstytuowały, wykorzystywany był, zwłaszcza w okresie irredenty styczniowej, a także w latach sprawowania funkcji generał-gubernatora wileńskiego przez Konstantina von Kaufmana, do prowadzenia polityki depolonizacyjnej w prowincjach północno-zachodnich.

49 S. Wiech, Litwa i Białoruś..., s. 155.

${ }^{50}$ Królestwo Polskie, „Czas” nr 33 z 10 II 1871 r., s. 3; zob. też: S. Wiech, Dyktatura serca na zachodnich rubieżach Cesarstwa Rosyjskiego. Dzieje kariery wojskowo-urzędniczej Piotra Albiedynskiego (1826-1883), Kielce 2010, s. 133.

${ }^{51}$ A. Komzołowa, op.cit., s. 287; zob. też: S. Wiech, Epoka reakcji i „,pieriedyszki”,.., s. 64. 
Nieudana próba realizacji tej strategii została podjęta wbrew liberalnym tendencjom części petersburskich elit politycznych. Formuła stanu wojennego wprowadzonego w guberniach zachodnich Cesarstwa Rosyjskiego była zatem zbliżona do klasycznych definicji wojny przyjmowanych na gruncie doktryn politycznych i prawnych, zwłaszcza teorii Carla von Clausewitza, iż wojna jest formą przemocy, która zmusza przeciwnika do określonego działania bez względu na koszty ${ }^{52}$. $\mathrm{Na}$ obszarze guberni północno-zachodnich przeciwnikiem tym była szlachta litewska oraz kler rzymskokatolicki.

\section{MARTIAL LAW IN THE NORTHWESTERN PROVINCES OF THE RUSSIAN EMPIRE AND ITS INFLUENCE ON THE LEGAL STATUS OF THE SUBJECTS OF EMPEROR ALEXANDER II (1855-1881)}

\section{Summary}

Between 1861 and 1872, martial law was in force in certain areas of the northwestern provinces of the Russian Empire (Vilnius, Kaunas, Grodno, Minsk, Vitebsk, and Mogilev). Over the course of more than a decade, the Russian authorities introduced a number of legal norms which were based on legal acts, called ukases (Russian $u k a z$ ), and administrative instructions. The norms directly and indirectly affected the scope of rights and responsibilities of the residents of these lands. Among them were mainly Lithuanian and Belarusian landowners as well as members of the Roman Catholic clergy. The article attempts to present the process of evolution of the Russian legislation which regulated the legal and personal status of the residents of the provinces, which made up Northwestern Krai of the Russian Empire, while martial law was in force.

LOI MARTIALE DANS LES PROVINCES DU NORD-OUEST DE L'EMPIRE DE RUSSIE ET SON INFLUENCE SUR LE STATUT JURIDIQUE DES SUJETS DE L'EMPEREUR ALEXANDRE II (1855-1881)

\section{Résumé}

Dans les années 1861-1872, la loi martiale était en vigueur dans les différents gouvernorats du Nord-Ouest (Vilnius, Kaunas, Grodno, Minsk, Vitebsk et Mohilev). Au cours de plus de dix années, les autorités russes, par le biais des ukases et des directives administratives, ont introduit un certain nombre de normes juridiques affectant directement et indirectement les droits et obligations des citoyens de ces régions, principalement des propriétaires fonciers lituano-biélorusses et du clergé catholique. Cet article tente de présenter l'évolution de la législation russe, durant la période d'application de la loi martiale, régissant le statut juridique et personnel des citoyens des provinces du Nord-Ouest qui faisaient partie de l'Empire de Russie.

${ }^{52}$ S. Górka, Doświadczenie wojen napoleońskich w życiu i myśli Carla von Clausewitza do roku 1815, „Politeja” 2003, nr 4, s. 67. 